\title{
INSECT DIVERSITY OF BUKIT HAMPUAN FOREST RESERVE, SABAH, MALAYSIA
}

\author{
A.Y.C. Chung ${ }^{1}$, S.K.F. Chew ${ }^{2}$, R. Majapun ${ }^{3} \&$ R. Nilus ${ }^{4}$ \\ 1,3,4 Forest Research Centre, Sabah Forestry Department, P.O. Box 1407, 90715 Sandakan, Sabah, Malaysia \\ ${ }^{2}$ Kipandi Butterfly Park, P. O. Box 12785, 88831 Kota Kinabalu, Sabah, Malaysia \\ ${ }^{1}$ arthur.chung@sabah.gov.my (corresponding author), ${ }^{2}$ chewichewlucanus@gmail.com, \\ ${ }^{3}$ richard.majapun@sabah.gov.my, ${ }^{4}$ reuben.nilus@sabah.gov.my
}

ISSN

Online 0974-7907

Print 0974-7893

OPEN ACCESS

\begin{abstract}
An insect diversity survey was carried out at Bukit Hampuan Forest Reserve, adjacent to Kinabalu Park in Sabah, Malaysia. The nocturnal insect diversity was very high, with a mean of 113 species recorded from one square metre of light-trapping cloth. Diurnal insects were sampled using sweep nets and fine forceps. A total of 19 Bornean endemic insect species were recorded, comprising 15 moth and four beetle species. A few of the endemic moths are confined to Sabah, namely Buzara saikehi, Cyana saulia and Lyclene mesilaulinea. Forty-two butterfly species were recorded. Endemic insect species sampled from this survey indicate the significance of protecting and conserving this forest reserve. Such findings provide important data to enhance the need and effort in biodiversity conservation. The recent gazettement of Bukit Hampuan Forest Reserve is appropriate, and it is also recommended that Bukit Hampuan Forest Reserve be connected to the adjacent Kinabalu Park, i.e. to gazette the connecting state land area into a forest reserve. Forest fires, illegal hunting for wild animals and orchids, and agricultural activities are among the threats to Bukit Hampuan Forest Reserve which directly affect its insect diversity. To mitigate these threats, it is important to adopt a multi-disciplinary and participatory approach in a smart partnership involving relevant stakeholders and the local communities in monitoring, enforcement and promoting environmental awareness.
\end{abstract}

Keywords: Biodiversity conservation, Bukit Hampuan, endemic, Heart of Borneo, Insect diversity.

Bahasa Malaysia Abstract: Satu tinjauan kepelbagaian serangga telah dijalankan di Hutan Simpan Bukit Hampuan, berdekatan dengan Taman Kinabalu di Sabah, Malaysia. Kepelbagaian serangga nokturnal amat tinggi, dengan purata 113 spesies direkodkan dalam satu meter persegi pada kain perangkap lampu. Serangga-serangga diurnal disampel menggunakan jaring sapu dan penyepit halus. Sebanyak 19 spesies serangga yang endemik di Borneo telah direkodkan, merangkumi 15 spesies rama-rama (moth) dan 4 spesies kumbang. Beberapa spesies rama-rama hanya terdapat di Sabah, iaitu Buzara saikehi, Cyana saulia dan Lyclene mesilaulinea. Empat puluh dua (42) spesies kupu-kupu (butterfly) telah direkodkan. Rekod spesies-spesies serangga yang endemik dari tinjauan ini mengesyorkan kepentingan untuk terus melindungi serta memulihara hutan simpan ini. Hasil-hasil kajian ini menyumbang kepada usaha-usaha pemuliharaan kepelbagaian Perwartaan Hutan Simpan Bukit Hampuan adalah tepat pada masanya. Adalah disyorkan juga hutan simpan ini disambung terus ke Taman Kinabalu, i.e. mewartakan kawasan bukan hutan simpan (stateland) yang menghubungkan hutan simpan berkenaan. Kebakaran hutan, pemburuan haram, pengambilan orkid serta aktiviti-aktiviti pertanian adalah antara ancaman kepada Hutan Simpan Bukit Hampuan, yang secara tidak langsung boleh mempengaruhi kepelbagaian serangga. Untuk mengatasi masalah-masalah ini, adalah penting bagi mengambil pendekatan multi-disiplin serta penyertaan yang melibatkan agensi-agensi yang berkaitan dan penduduk tempatan dalam pengawasan, penguatkuasaan dan juga mempergiatkan kesedaran persekitaran.

DOI: http://dx.doi.org/10.11609/JoTT.o3243.4461-73 | ZooBank: urn:Isid:zoobank.org:pub:12D0FF1A-86CD-408E-94AD-9EB91D8E280E

Editor: B.A. Daniel, Zoo Outreach Organization, Coimbatore, India.

Date of publication: 26 June 2013 (online \& print)

Manuscript details: Ms \# 03243 | Received 29 June 2012 | Final received 12 May 2013 | Finally accepted 01 June 2013

Citation: Chung, A.Y.C., S.K.F. Chew, R. Majapun \& R. Nilus (2013). Insect diversity of Bukit Hampuan Forest Reserve, Sabah, Malaysia. Journal of Threatened Taxa 5(10): 4461-4473; http://dx.doi.org/10.11609/JoTT.03243.4461-73

Copyright: @ Chung et al. 2013. Creative Commons Attribution 3.0 Unported License. JoTT allows unrestricted use of this article in any medium, reproduction and distribution by providing adequate credit to the authors and the source of publication.

Funding: Ministry of Natural Resources \& Environment, Malaysia through the Sabah Forestry Department (the logo provided is Sabah Forestry Department).

Competing Interest: None.

Acknowledgements: This is part of the Heart of Borneo (HoB) Programme with funding from the $9^{\text {th }}$ Malaysian Plan through the Federal Ministry of Natural Resources \& Environment (NRE). Within the Sabah Forestry Department, this programme is managed under the Deputy Director (Forest Sector Planning), Mr. Frederick Kugan. The Director of Sabah Forestry Department, Datuk Sam Mannan, Deputy Director (R\&D), Dr. Lee Ying Fah and Head of FRC Insect Diversity Programme, Dr. Chey Vun Khen are acknowledged for their support.

Author Contribution: AYCC, RN \& RM participated in this survey. SKFC is an expert on beetles and other montane insects, and he has contributed significantly in identification.

Author Details: ARTHUR Y.C. CHUNG and STEVEN K.F. CHEW are entomologists based in Sabah. AYCC is a senior researcher at the Sabah Forestry Department with a DPhil on tropical entomology from Oxford University. REUBEN NILUS is a senior researcher on forest ecology while RICHARD MAJAPUN is a researcher of the same institution 


\section{INTRODUCTION}

Malaysia is one of the 12 mega-biodiverse countries in the world, and much attention has been focussed on biodiversity conservation (e.g., Yong 2009; CVB 2010). Insects contribute significantly to the high biodiversity of Malaysian rainforests. They are ubiquitous in the environment and play important roles in maintaining the stability of ecosystems by being part of the food chain, mediating decomposition processes and through various ecological interactions such as pollination, predation and herbivory (Cheng \& Kirton 2007).

Despite the loss of forest cover in the last 40 years, more than half of the land area in Sabah is still covered with forests (Mannan 2011). The state government, through the Sabah Forestry Department, has been proactive in implementing various programs that contribute to sustainable forest management, such as the Heart of Borneo ( $\mathrm{HoB}$ ) initiative. About $39,000 \mathrm{~km}^{2}$ of the state's landmass has been set aside for this initiative, mainly comprising important inland and highland forest ecosystems, with the main objective to protect and conserve the biodiversity of these areas, including insects (Chung et al. 2011). Bukit Hampuan is a recently gazetted forest reserve that lies within the HoB area (Fig. $1)$.

Under the HoB programme, the purpose of this study was to document the insect fauna of the Bukit Hampuan Forest Reserve (FR) and to investigate the threats affecting insect diversity, as well as to provide recommendations that would contribute towards biodiversity conservation of the study area.

\section{MATERIALS AND METHODS}

Bukit Hampuan FR is a Class I Forest Reserve which was only recently gazetted in 2009 (SFD 2010a). It is conserved primarily for environmental protection and biodiversity conservation, protected by law from any form of land conversion or timber exploitation.

In the forest reserve classification, Bukit Hampuan

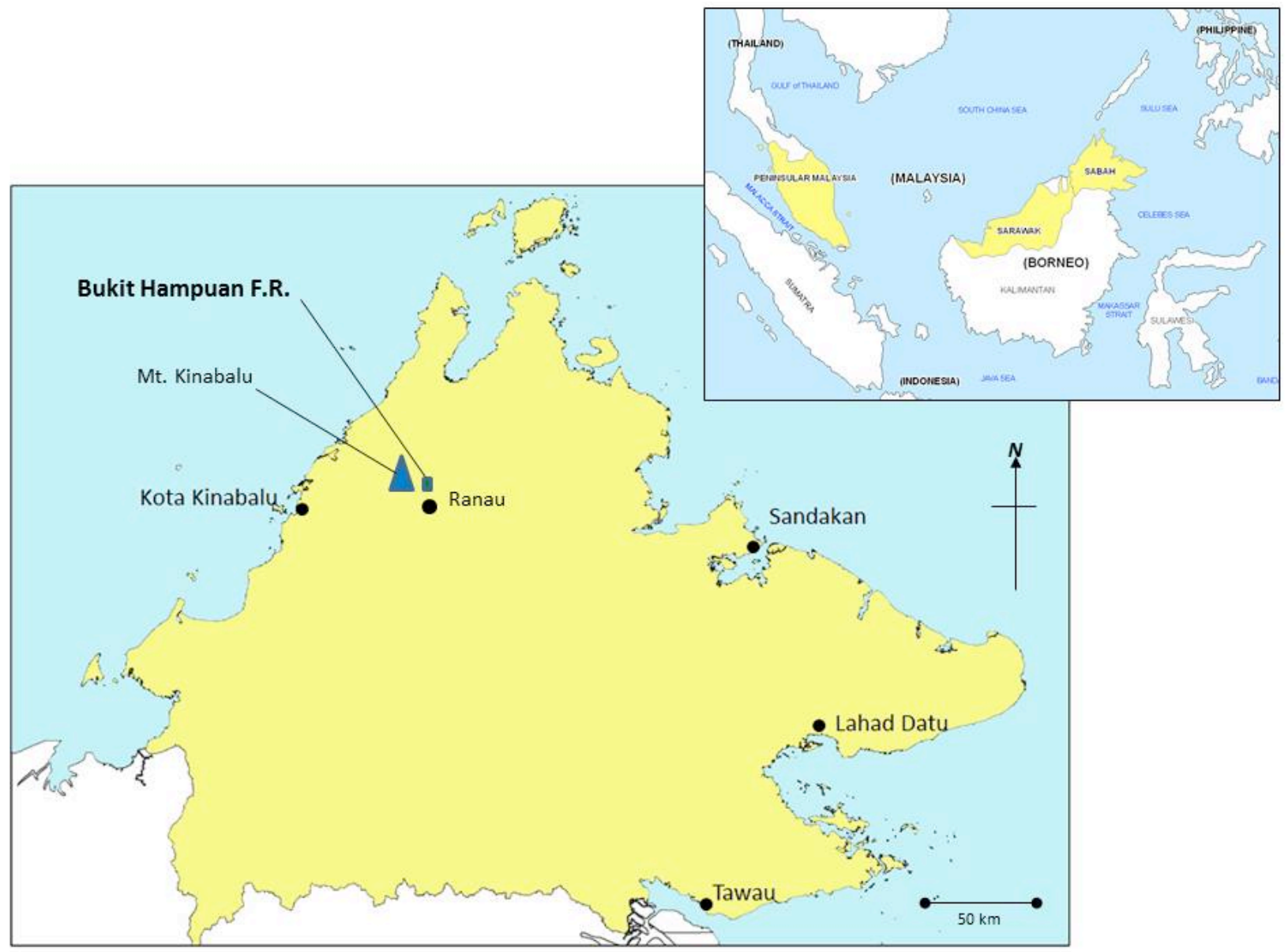

Figure 1. Location of Bukit Hampuan Forest Reserve in Sabah. Inset: Sabah is one of the Malaysian states in Borneo. 
FR covers a relatively small area of $1,253 \mathrm{ha}$, under the jurisdiction of the District Forestry Officer of Ranau. The vegetation consists of upland dipterocarp forest to lower montane forest, with the elevation ranging from 670-1,500 m. However, much of the reserve at the lower elevation has been degraded, mainly due to forest fire and human activities in the past. Nilus et al. (2012) provided the details of botanical and forest assessments of this ultramafic forest reserve.

An abandoned massive pit of the former Mamut Copper Mine (MCM) is located at the fringe (northwest) of this reserve. The mine was in operation from 1975-1999. The pit formed a lake at the bottom, with greenish-blue, highly acidic and metal-contaminated water, unsafe for consumption. It is a restricted area under the management of the Federal Department of Minerals and Geoscience.

Bukit Hampuan FR is also situated adjacent to Kinabalu Park, separated by stateland at the north, at a distance of less than $2 \mathrm{~km}$. This forest reserve is also significant as a water catchment area for some of the villages, especially $\mathrm{Kg}$. Lohan and $\mathrm{Kg}$. Kilimu. The source of the water is from the streams within the forest reserve, and not originated from the copper mine lake.

The study was conducted as part of the Bukit Hampuan expedition under the Heart of Borneo ( $\mathrm{HoB}$ ) programme of the Sabah Forestry Department from 10 to 14 May, 2010. The base camp was at Kg. Kilimu $\left(05^{\circ} 58^{\prime} 52^{\prime \prime} \mathrm{N} \& 116^{\circ} 40^{\prime} 37^{\prime \prime} \mathrm{E}\right.$, at $573 \mathrm{~m}$ elevation), a village located beside the Ranau-Kota Kinabalu highway, south of Bukit Hampuan FR.

Light trap was used to sample nocturnal insects while sweep net and manual collecting (with forceps) were used to sample diurnal insects.

\section{Light trap}

The trap consists of a vertical white sheet $(2 \times 2 \mathrm{~m})$ illuminated by a $250 \mathrm{~W}$ mercury-lithium bulb. It was set up in an open area facing the forest reserve, from 19:00-21:00 hr. A GPS (Model: Garmin etrex Vista) was used to determine the coordinates of each sampling site (Table 1). To evaluate diversity of the sampling area, insect species and individuals ( $\geq 5 \mathrm{~mm}$ in length) within the $1 \times 1 \mathrm{~m}$ square of the white cloth were enumerated from 20:30-21:00 hr. This is a rapid biodiversity assessment method because by the end of the sampling time, species and individual numbers can be obtained, and the data can be used to calculate diversity indices, i.e. Shannon Wiener, Simpson and Fisher Alpha, using Species Diversity \& Richness version IV (SDR 2006). This method is simple, fast and can be carried out by non-
Table 1. Light-trapping sites at Bukit Hampuan Forest Reserve

\begin{tabular}{|l|c|l|l|l|}
\hline $\begin{array}{l}\text { Sampling } \\
\text { site }\end{array}$ & Coordinates & $\begin{array}{l}\text { Elevation } \\
(\mathrm{m})\end{array}$ & $\begin{array}{l}\text { Sampling } \\
\text { date }\end{array}$ & Remarks \\
\hline Hampuan 1 & $\begin{array}{c}06^{\circ} 00^{\prime} 42^{\prime \prime} \mathrm{N} \\
\& \\
116^{0} 39^{\prime} 19^{\prime \prime} \mathrm{E}\end{array}$ & 1,347 & $11 . v .2010$ & $\begin{array}{l}\text { Cold and } \\
\text { misty night, } \\
\text { without } \\
\text { moonlight }\end{array}$ \\
\hline Hampuan 2 & $\begin{array}{c}06^{\circ} 01^{\prime} 24.9^{\prime \prime} \mathrm{N} \\
\& \\
116^{0} 39^{\prime} 46^{\prime \prime} \mathrm{E}\end{array}$ & 1,493 & $12 . v \cdot 2010$ & $\begin{array}{l}\text { Raining } \\
\text { and heavy } \\
\text { mist during } \\
\text { sampling, } \\
\text { without } \\
\text { moonlight. }\end{array}$ \\
\hline Hampuan 3 & $\begin{array}{c}\mathrm{N}^{\prime} 06^{\circ} 00^{\prime} 49.8^{\prime \prime} \\
\mathrm{E} 116^{\circ} 39^{\prime} 19.3^{\prime \prime}\end{array}$ & 1,365 & $13 . v \cdot 2010$ & $\begin{array}{l}\text { Windy and } \\
\text { drizzling } \\
\text { during } \\
\text { sampling, } \\
\text { without } \\
\text { moonlight. }\end{array}$ \\
\hline
\end{tabular}

Table 2. Daytime sampling sites at Bukit Hampuan Forest Reserve

\begin{tabular}{|c|l|c|c|c|}
\hline & Sampling site & $\begin{array}{c}\text { Starting point } \\
\text { coordinates }\end{array}$ & $\begin{array}{c}\text { Elevation } \\
(\mathbf{m})\end{array}$ & $\begin{array}{c}\text { Sampling } \\
\text { distance } \\
(\mathbf{k m})\end{array}$ \\
\hline 1 & $\begin{array}{l}\text { Mamut Copper } \\
\text { Mine graveled road }\end{array}$ & $\begin{array}{c}06^{\circ} 00^{\prime} 42^{\prime \prime} \mathrm{N} \& \\
116^{0} 39^{\prime} 19^{\prime \prime} \mathrm{E}\end{array}$ & $1,345-1,495$ & 2 \\
\hline 2 & $\begin{array}{l}\text { Mamut Copper } \\
\text { Mine area }\end{array}$ & $\begin{array}{c}06^{\circ} 01^{\prime} 59^{\prime \prime} \mathrm{E} \& \\
116^{0} 39^{\prime} 14^{\prime \prime} \mathrm{N}\end{array}$ & $1,345-1,362$ & 2 \\
\hline 3 & $\begin{array}{l}\text { Kg. Lohan Bongkud } \\
\text { area }\end{array}$ & $\begin{array}{c}06^{\circ} 00^{\prime} 52^{\prime \prime} \mathrm{N} \& \\
116^{\circ} 41^{\prime} 41^{\prime \prime} \mathrm{E}\end{array}$ & $677-775$ & 1 \\
\hline 4 & $\begin{array}{l}\text { Bukit Hampuan } \\
\text { open area }\end{array}$ & $\begin{array}{c}06^{\circ} 01^{\prime} 06^{\prime \prime} \mathrm{N} \& \\
116^{0} 39^{\prime} 51^{\prime \prime} \mathrm{E}\end{array}$ & $1,367-1,400$ & 1 \\
\hline
\end{tabular}

insect specialists. To avoid compounding human error, the same staff was assigned to count the species and individual numbers throughout the sampling period.

\section{Sweep net and manual collection}

Sweep nets were used to collect flying insects, such as butterflies and dragonflies while other insects were sampled using fine forceps. Butterflies and dragonflies were put in triangle papers while other specimens were put in vials with $75 \%$ ethanol solution. Most of the trails were going up the slope (mostly 20\%) heading towards the ridge or peak within the area.

\section{Insect specimens and identification}

This survey focussed on certain insect groups, i.e., butterflies, moths, beetles, cicadas and dragonflies. Only insect species of high importance (e.g., those based on Otsuka (1988), Tung (1983), Holloway (1996b) and Orr (2003)) were sampled, as to minimize the workload at the laboratory in preparing the specimens for identification. Common insects were not sampled but photographed for record purposes. 
All specimens were dry-mounted and sorted to family and some to the generic and species level. The specimens sampled from this study are deposited at the Forest Research Centre (FRC), Sepilok, Sabah. Drymounted specimens were identified based on the FRC Entomology Collection and various reference materials, e.g. Otsuka (1988 \& 2001) and Corbet \& Pendlebury (1992) for butterflies; Holloway (1983, 1985, 1986, 1988, 1989, 1993, 1996a, 1997, 1998a \& b, 1999, 2001, 2003, 2005, 2008 \& 2009) and Robinson et al. (1994) for moths; Mizunuma \& Nagai (1994), Makihara (1999) and Tung (1983) for beetles; Orr (2003) for dragonflies. Dr. Bakhtiar Effendi Yahya of Universiti Malaysia Sabah assisted in ant identification.

\section{RESULTS AND DISCUSSION}

\section{Overall nocturnal insect diversity}

Despite the degraded areas within the Bukit Hampuan FR, the nocturnal insect diversity was very high, with a mean of 113 species within a $1 \mathrm{~m}^{2}$. The high diversity is reflected in various diversity indices in Table 3. A total of 125 insect species were recorded from a $1 \mathrm{~m}^{2}$ at the first night of light-trapping (Hampuan 1), at the elevation of $1,347 \mathrm{~m}$. However, the diversity indices were comparatively low because of a hymenopteran species with 90 individuals. It was the nuptial flight of this flying ant. Of all the indices, the low diversity value at Hampuan 1 was obvious on the Simpson's Index, which is more sensitive towards dominant species. The species distribution was very even in Hampuan 3 (as each species is represented by 1.1 individuals; see Table 3), followed by Hampuan 2 (one species recorded 13 individuals), compared to Hampuan 1 with a distinct prominent species. The distribution of nocturnal insect species from the three sites is reflected in the speciesrank abundance curves in Fig. 2. Although it was raining with heavy mist on day two (Hampuan 2) and drizzling on day three (Hampuan 3) of the light-trapping, insect diversity as indicated by Shannon, Simpson and Fisher Alpha indices were impressively high.

When the nocturnal insect diversity results are compared with other forest reserves in Sabah, Bukit Hampuan FR appears to be impressively high, second to Crocker Range FR as indicated in species richness (Fig. 3a) and Shannon's Index (Fig. 3b). The results also indicate that insect diversity is generally higher in the lower montane forests.

Such high diversity for insects from 670-1500 m

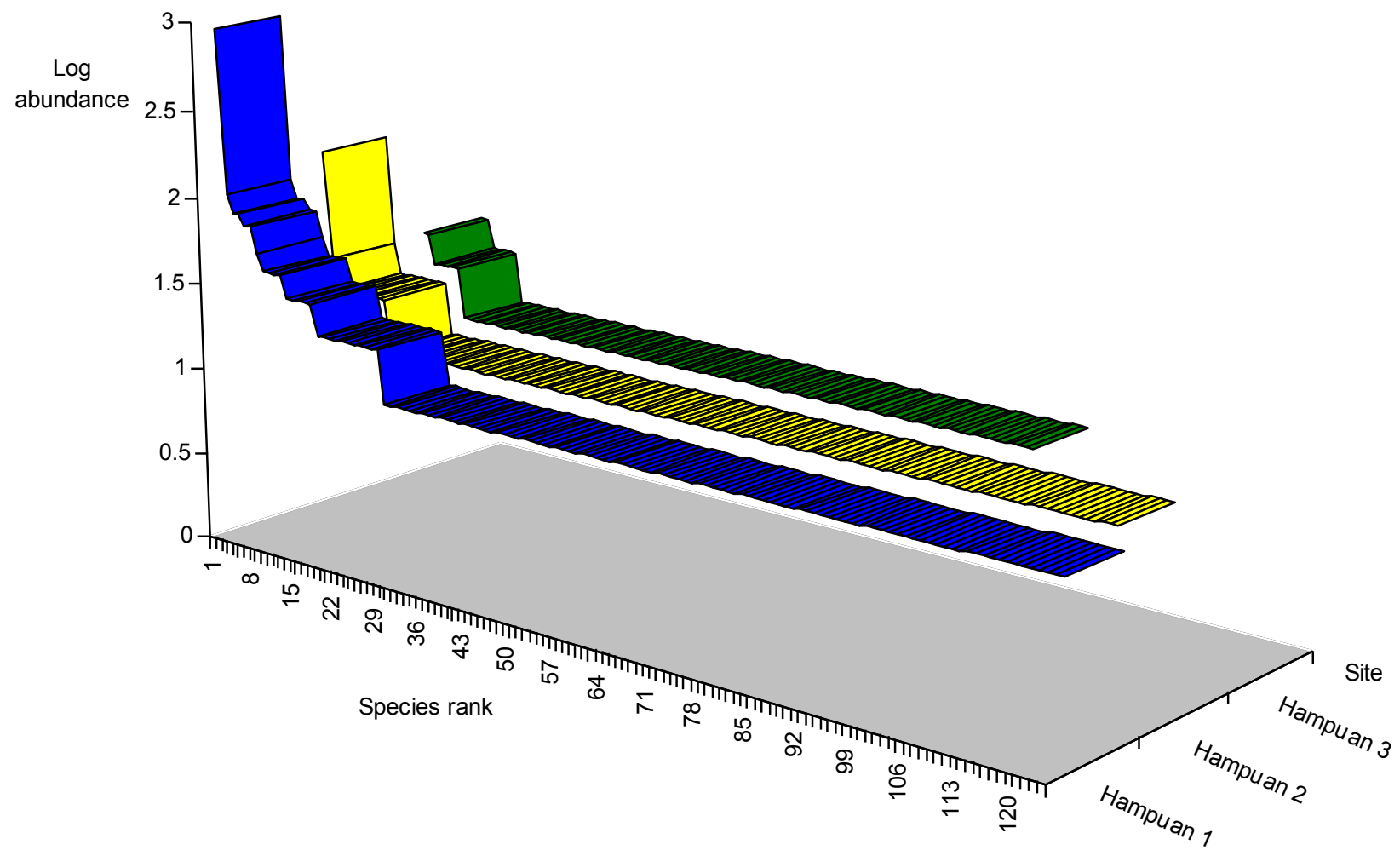

Figure 2. Species-rank abundance curves of the sampling sites at Bukit Hampuan Forest Reserve. 
Table 3. Insect diversity within a $1 \mathrm{~m}^{2}$ as sampled through light-trapping at Bukit Hampuan Forest Reserve

\begin{tabular}{|l|l|c|c|c|c|c|}
\hline & Sampling site & Species & Ind. & Shannon & Simpson & Fisher Alpha \\
\hline 1 & Hampuan 1 & 125 & 286 & 3.73 & 9.69 & 84.64 \\
\hline 2 & Hampuan 2 & 119 & 142 & 4.61 & 111.23 & 346.35 \\
\hline 3 & Hampuan 3 & 96 & 105 & 4.53 & 496.40 & 543.44 \\
\hline & Mean( \pm SD) & $113 \pm 15$ & $178 \pm 96$ & $4.29 \pm 0.5$ & $205.77 \pm 256.76$ & $324.81 \pm 230.16$ \\
\hline
\end{tabular}

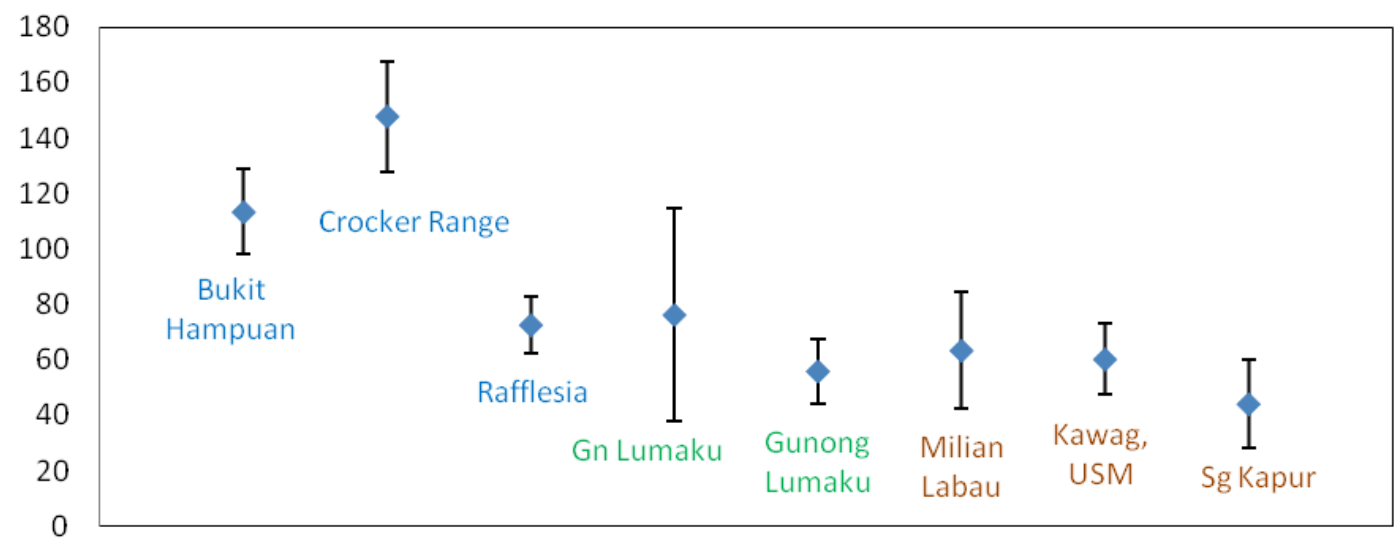

Figure 3a. Species number ( \pm standard deviation) within one square metre as assessed through light-trapping at various forest reserves in Sabah (blue text = lower montane forest, green text = upland dipterocarp forest and brown text = lowland dipterocarp forest).

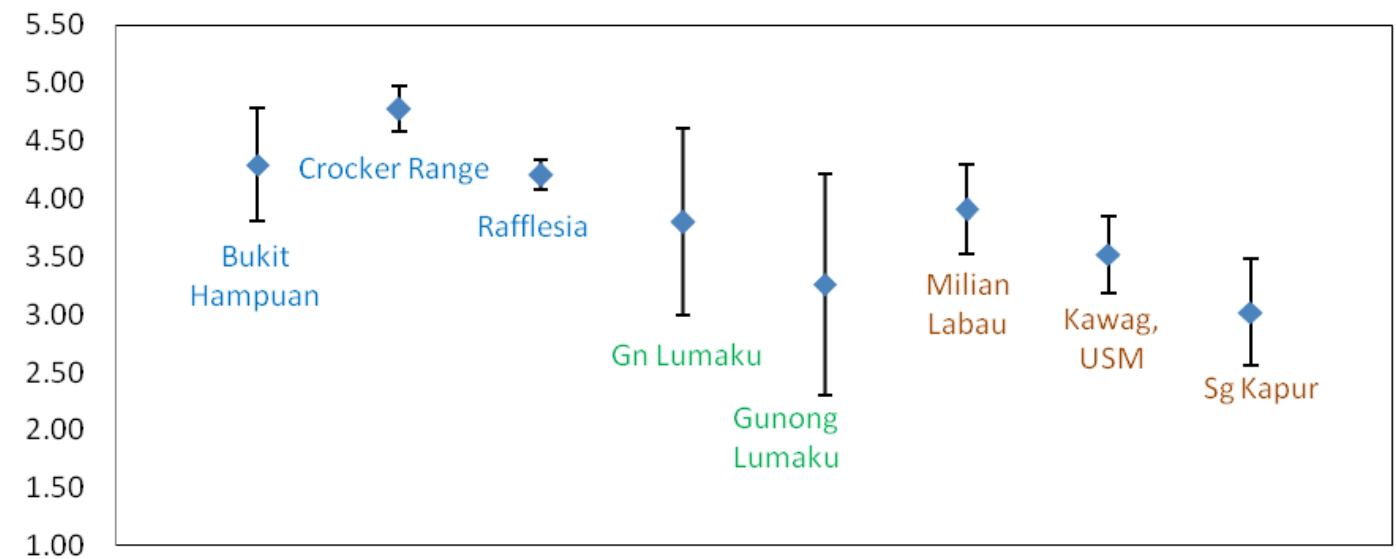

Figure 3b. Shannon's Index ( \pm standard deviation) within one square metre as assessed through light-trapping at various forest reserves in Sabah (blue text = lower montane forest, green text = upland dipterocarp forest and brown text = lowland dipterocarp forest).

could be due to its proximity to the pristine Kinabalu Park. As highlighted by Wong \& Phillips (1996) and Holloway (1996b), the insect life of Mount Kinabalu is one of the most enthralling ever known and continues to perplex the most experienced of scientists. It is also incredibly rich in endemic species. A total of 19 Bornean endemic insect species were recorded within a short sampling period (Table 4). In the same survey, 66 Bornean endemic plant species were recorded, including
Microtropis sabahensis (Celastraceae) which is confined to Sabah and Pittosporum linearifolium (Pittosporaceae) which is only found at Bukit Hampuan FR (Nilus et al. 2012). Beaman (1996), Meijer (1996) and Corner (1996) noted that the rare and endemic plants within the Mount Kinabalu area are mainly due to its ultramafic geology, cold climate and high elevation. 
Table 4. Bornean endemic insect species recorded from Bukit Hampuan Forest Reserve during the survey.

\begin{tabular}{|c|c|c|c|c|}
\hline & Order & Family (Subfamily) & Species & Author \\
\hline 1 & Lepidoptera (Moth) & Arctiidae (Arctiinae) & Aethalida borneana & Holloway \\
\hline 2 & Lepidoptera (Moth) & Arctiidae (Arctiinae) & Nyctemera kinibalina & Snellen \\
\hline 3 & Lepidoptera (Moth) & Arctiidae (Arctiinae) & Spilosoma groganae & Holloway \\
\hline 4 & Lepidoptera (Moth) & Arctiidae (Lithosiinae) & Adites hosei & Holloway \\
\hline 5 & Lepidoptera (Moth) & Arctiidae (Lithosiinae) & Barsine euprepia & Hampson \\
\hline 6 & Lepidoptera (Moth) & Arctiidae (Lithosiinae) & Cyana cruentata & Talbot \\
\hline 7 & Lepidoptera (Moth) & Arctiidae (Lithosiinae) & Cyana saulia & Swinhoe \\
\hline 8 & Lepidoptera (Moth) & Arctiidae (Lithosiinae) & Lyclene mesilaulinea & Holloway \\
\hline 9 & Lepidoptera (Moth) & Arctiidae (Lithosiinae) & Lyclene multiramorum & Holloway \\
\hline 10 & Lepidoptera (Moth) & Arctiidae (Syntominae) & Auriculoceryx pterodactyliformis & Holloway \\
\hline 11 & Lepidoptera (Moth) & Cossidae & Zeuzera borneana & Roepke \\
\hline 12 & Lepidoptera (Moth) & Geometridae (Geometrinae) & Spaniocentra megaspilaria & Guenee \\
\hline 13 & Lepidoptera (Moth) & Noctuidae (Aganainae) & Asota kinabaluensis & Rothschild \\
\hline 14 & Lepidoptera (Moth) & Noctuidae (Catocalinae) & Buzara saikehi & Holloway \\
\hline 15 & Lepidoptera (Moth) & Thyrididae & Banisia intonsa & Whalley \\
\hline 16 & Coleoptera (Beetle) & Cerambycidae & Neosarmydus costipennis & Fisher \\
\hline 17 & Coleoptera (Beetle) & Lucanidae & Cyclommatus giraffa & Mollenkamp \\
\hline 18 & Coleoptera (Beetle) & Scarabaeidae & Chalcosoma moellenkampi & Kolbe \\
\hline 19 & Coleoptera (Beetle) & Scarabaeidae & Fruhstoferia nigromuliebris & Nagai \\
\hline
\end{tabular}

\section{Butterfly (Lepidoptera) diversity}

A total of 42 butterfly species were recorded from Bukit Hampuan FR (Appendix 1). Comparatively, the diversity was lower compared to $\mathrm{Gn}$. Lumaku and Imbak Canyon (Table 5). Distribution of species is shown in Fig. 4. Many of the butterflies were sampled between 680 $-780 \mathrm{~m}$ at the fringe of the upland dipterocarp forest at $\mathrm{Kg}$. Lohan Bongkud. Fewer specimens were sampled along the Mamut Copper Mine road but the Kinabalu Bush Orange, Mycalesis marginata pitan which is only found in Sumatra and Borneo, was sampled here.

The large and iconic butterfly species recorded from Bukit Hampuan FR were the Rajah Brooke's Birdwing (Troides brookiana), the Common Birdwing (Troides helena) and the Tree Nymph (Idea stolli). A number of Bornean endemic butterflies are found in the Kinabalu region (Otsuka 1988) but unfortunately none of them were sampled during this survey.

\section{Moth (Lepidoptera) diversity}

Various moth species were attracted to the light trap set up at three locations facing the forest of Bukit Hampuan between 1,350-1,500 m. A list of the recorded moths is provided in Appendix 2 \& 3 . Fifteen Bornean endemic moth species were recorded from this survey, namely 10 species from Arctiidae, one Cossidae, one Geometridae, two Noctuidae and one Thyrididae (Image 1). It is not surprising that many endemics were sighted, as Holloway (1996b) has noted that the Mount Kinabalu area is high in moth endemism, with 112 macro-moth species recorded only from Kinabalu.

Some of the endemic species are only found in Sabah. The noctuid Buzara saikehi is a hyper-endemic, as it is only recorded from the Mamut, Ranau and the holotype is in the FRC collection at Sepilok (Holloway 2005). It was named after the late Saikeh Lantoh, a senior research assistant at FRC. In this survey, it was attracted to the light trap at Hampuan 1 (1,347m). Other Sabah endemics sampled were the arctiid Cyana saulia and Lyclene mesilaulinea. Cyana saulia was previously recorded from Paitan at the coast of Sabah while Lyclene mesilaulinea was sampled from Mesilau and Mt. Monkobo (Holloway 2001).

Nyctemera kinibalina and Nyctemera tripunctaria (both Arctiidae) are day-flying moths and they were sampled with the sweep net at the Mamut Copper Mine road. Nyctemera muelleri, however, was attracted to the light trap. 
Table 5. Comparison of butterfly diversity between Bukit Hampuan Forest Reserve, Gn. Lumaku Forest Reserve and Imbak Canyon Conservation Area.

\begin{tabular}{|l|l|c|c|c|c|c|}
\hline Sampling site & Method & Species & Ind. & Shannon & Simpson & Fisher Alpha \\
\hline Bukit Hampuan Forest Reserve & Sweep net \& observation & 42 & 78 & 3.48 & 31.95 & 37.09 \\
\hline Gg. Lumaku Forest Reserve & Sweep net \& observation & 52 & 106 & 3.56 & 29.76 & 40.37 \\
\hline Imbak Canyon* & $\begin{array}{l}\text { Fruit bait, sweep net \& } \\
\text { observation }\end{array}$ & 72 & 133 & 4.09 & 70.22 & 64.10 \\
\hline
\end{tabular}

* Source: Lim-Hasegawa \& Chey (2009)

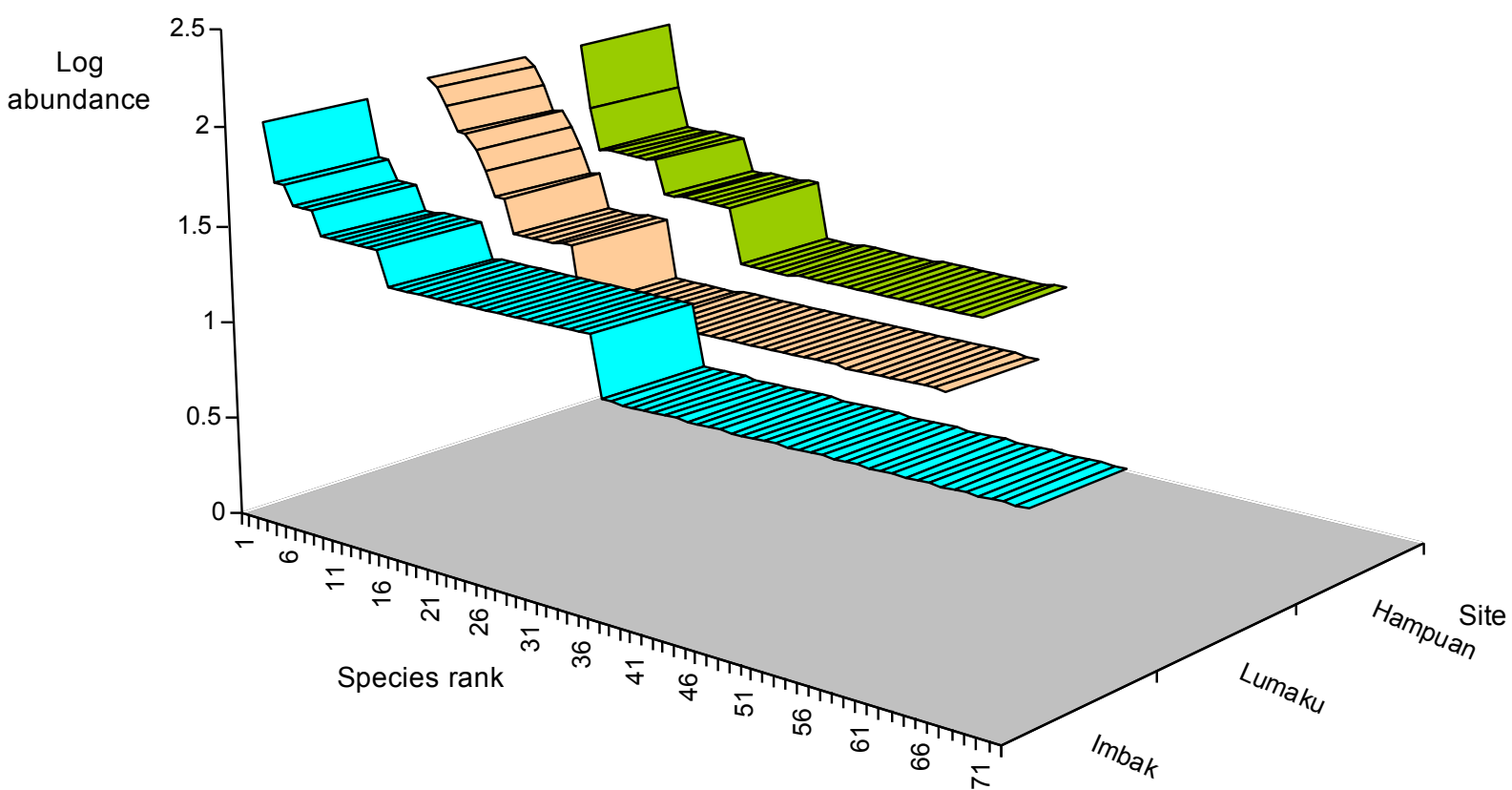

Figure 4. Species-rank abundance curves of butterflies sampled from Imbak Canyon Conservation Area, Gn. Lumaku F.R. and Bukit Hampuan Forest Reserve

\section{Beetle (Coleoptera) diversity}

A total of 26 species of macro-beetles were recorded (Appendix 4). Many were sampled through lighttrapping. At least four species are endemic to Borneo, namely Fruhstoferia nigromuliebris, Neosarmydus costipennis, Cyclommatus giraffa and Chalcosoma moellenkampi. The first two species are rare while Cyclommatus giraffa is confined to the montane areas, such as Kinabalu Park and Crocker Range. The Threehorned Beetle Chalcosoma moellenkampi is common throughout Sabah although it is only found in Borneo.

\section{Other insects}

Unlike butterflies, moths and beetles, no concerted effort was deployed to sample other insect groups. However, a few species of cicadas and dragonflies were sampled, as listed in Appendix 5. Some dragonfly species were sampled along the streams in the forest adjacent to
Kg. Lohan Bongkud, e.g. Macromia westwoodii at about $700 \mathrm{~m}$ while others were collected at the Bukit Hampuan FR open area at $1,370 \mathrm{~m}$, e.g. Pantala flavescens. Macromia westwoodii is a large dragonfly, with its hindwing measuring up to $50 \mathrm{~mm}$. It is fairly common on clear fast forest streams from the lowlands to $900 \mathrm{~m}$ but is extremely inconspicuous and wary. Pantala flavescens is the most wide ranging odonate species in the world, being found throughout the tropics and subtropics, from dense primary forest up to at least 3000m (Orr 2003).

A striking Yellow-banded Cicada Tacua speciosa, measuring $55 \mathrm{~mm}$, was collected at about $1,500 \mathrm{~m}$ during daytime by the Botany team. It is also known as the 'Emperor Cicada'. Two species of unidentified Hemiptera, from the family Tomaspididae were also sampled, from about $1,400 \mathrm{~m}$.

Myrmicaria ants were frequently encountered feeding on extrafloral nectaries of wild orchids along the 
Mamut Copper Mine road. It is likely to be Myrmicaria subcarinata, but it could be more than one species (Bakhtiar E. Yahya, pers. comm. June 2010).

\section{Threats and recommendations for insect diversity and conservation at Bukit Hampuan FR}

Prior to the recent gazettement of Bukit Hampuan as a Class I Forest Reserve in 2009, the area was under stateland status. About $28 \%$ of the area is classified as degraded due to series of forest fires in the past, and $2 \%$ was encroached for agricultural activities (Nilus et al. 2012).

The northwestern part of Bukit Hampuan FR was part of the copper mining area, covering about $87 \mathrm{ha}$. This is the area where the overburdens and waste rocks from the mining pit were dumped. The vegetation in this area is poor and sparse. The trees planted by the copper mine management were stunted, e.g., Falcataria moluccana. Only certain plant species were found to be growing well. As such, the overall biodiversity within the present Bukit Hampuan FR is not spectacular, compared to the adjacent pristine Kinabalu Park, with the exception of the nocturnal insects sampled from this survey. Insects, such as moths and beetles are very mobile, and they could have traveled from the adjacent pristine forest. Kinabalu Park is less than $2 \mathrm{~km}$ north of Bukit Hampuan FR nevertheless, the high diversity of nocturnal insects may suggest that Bukit Hampuan FR is still conducive, providing suitable habitats for many of these insects because of the cool environment.

To sustain and improve the biodiversity of Bukit Hampuan FR, it is, thus, highly recommended that the area between the reserve at the northern part and Kinabalu Park be gazetted as a forest reserve. This area which is presently under the stateland status is still in pristine forest condition, but it is subject to any land-use changes and development. By gazetting to a Class I Forest Reserve, the area will be fully protected by law and any encroachment can be penalized. This connectivity will be permanent and it will allow wildlife (especially large animals) to move about from Bukit Hampuan to Kinabalu Park and vice versa. It will also indirectly enhance the diversity of insects in Bukit Hampuan FR.

The State Culture, Tourism and Environment Minister, Datuk Masidi Manjun noted that connectivity and corridors have been overlooked. Even with more than $50 \%$ forest cover in Sabah, conservation will not be effective if the fragmented forests are not connected. Lately, the State Government through the Sabah Forestry Department as well as other agencies, has put in much concerted effort in highlighting the importance of forest connectivity and wildlife corridors, and discussed the way forward in implementation (SFD 2010b).

Forest fire is a common problem in forest reserves during drought. The impact is irreversible, as seen in some degraded areas in Bukit Hampuan FR. To prevent further damage by fire, the forest staff would have to be more alert and work together with the kampung folks on this matter, e.g., via appointment of honorary forest wardens. Environmental awareness and education can be promoted and enhanced among the villagers and their children on the importance of forest and its services. Such awareness will also help to curb illegal hunting for wild animals and orchids, which were common in Bukit Hampuan in the past. For effective implementation, it is important to adopt a multi-disciplinary and participatory approach involving relevant stakeholders, such as Wildlife Department, Environmental Protection Department, Education Department, Fire \& Rescue Department, NGOs and the local communities. Funding from local, as well as international agencies would greatly contribute towards the success of the implementation.

Constant monitoring and enforcement by the relevant authorities will minimize encroachment into the forest reserve. Setting up of gates and warning signs at restricted areas would hopefully reduce the number of trespassers. Signage at the forest reserve border will remind the villagers of the boundary and limit of land clearing for agriculture.

\section{CONCLUSION}

The nocturnal insect diversity at Bukit Hampuan FR was impressively high despite some degraded areas within the forest reserve. Many endemic insect species sampled from this survey within a short period indicates the significance of protecting and conserving this forest reserve. Such findings provide important data to enhance the need and effort in biodiversity conservation. The recent gazettement of Bukit Hampuan as a Class I Forest Reserve is appropriate and timely. It is also crucial for Bukit Hampuan FR to be connected to Kinabalu Park, i.e., to gazette the connecting stateland area into a Class I Forest Reserve. This connectivity is the prime means of physically linking wildlife habitat and allow some species to move between otherwise isolated area. It can help to replenish isolated populations. Ideally, the connectivity itself also meets some or all of the need for shelter, protection, food and breeding sites. Constant monitoring, enforcement, cooperation with relevant stakeholders and local communities, and 
promotion of environmental awareness are among the recommendations to mitigate the threats in Bukit Hampuan FR.

\section{REFERENCES}

Beaman, J.H. (1996). Evolution and phytogeography of the Kinabalu flora, pp. 95-99. In: Wong, K.M. \& A. Phillips (eds.). Kinabalu: summit of Borneo. The Sabah Society \& Sabah Parks.

Cheng, S. \& L.G. Kirton (2009). Overview of insect biodiversity research in Peninsular Malaysia, pp. 121-128. In: Chua, L.S.L., L.G. Kirton \& L.G. Saw (eds.). Status of biological diversity in Malaysia and threat assessment of plant species in Malaysia. Proceedings of the Seminar \& Workshop, 28-30 June, 2005. FRIM, KL.

Chung, A.Y.C., R. Majapun, R. Nilus \& F. Kugan (2011). Insect diversity within the Heart of Borneo ( $\mathrm{HoB})$ in Sabah: research undertaken by the Sabah Forestry Department, pp. 79-90. In: Gan, K.S., S. Mahmudin \& M.Y. Mohd. Nor (eds.). Proceedings of the International Symposium on Forestry \& Forest Products - Addressing Global Concerns \& Changing Societal Needs. Forest Research Institute Malaysia.

Corner, E.J.H. (1996). The plant life of Kinabalu - an introduction, pp. 101-149. In: Wong, K.M. \& A. Phillips (eds.). Kinabalu: summit of Borneo. The Sabah Society \& Sabah Parks.

CVB (2010). A Common Vision on Biodiversity - in Government and the Development Process. The Ministry of Natural Resources and Environment, Putrajaya, 111pp.

Holloway, J.D. (1983). Moths of Borneo (part 4): family Notodontidae Malayan Nature Journal 37: 1-107.

Holloway, J.D. (1985). Moths of Borneo (part 14): Family Noctuidae: subfamilies Euteliinae, Stictopterinae, Plusiinae, Pantheinae Malayan Nature Journal 38: 157-317.

Holloway, J.D. (1986). Moths of Borneo (part 1): key to families: families Cossidae, Metarbelidae, Ratardidae, Dudgeoneidae, Epipyropidae and Limacodidae. Malayan Nature Journal 40: 1-166.

Holloway, J.D. (1988). The Moths of Borneo (Part 6): Family Arctiidae, Subfamilies Syntominae, Euchromiinae, Arctiinae; Noctuidae Misplaced In Arctiidae (Camptoloma, Aganainae). Southdene Sdn. Bhd., Kuala Lumpur, $101 \mathrm{pp}$.

Holloway, J.D. (1989). The Moths of Borneo (Part 12): Family Noctuidae, Trifine Subfamilies: Noctuinae, Heliothinae, Hadeninae, Acronictinae, Amphipyrinae, Agaristinae. Southdene Sdn. Bhd. Kuala Lumpur, 226pp.

Holloway, J.D. (1993). The Moths of Borneo (Part 11): Family Geometridae, Subfamily Ennominae. Southdene Sdn. Bhd., Kuala Lumpur, 309pp.

Holloway, J.D. (1996a). The moths of Borneo (part 9): family Geometridae, subfamilies Oenochrominae, Desmobathrinae and Geometrinae. Malayan Nature Journal 49: 147-326.

Holloway, J.D. (1996b). Butterflies and moths, pp. 291-313. In: Wong, K.M. \& A. Phillips (eds.). Kinabalu: summit of Borneo. The Sabah Society \& Sabah Parks.

Holloway, J.D. (1997). The moths of Borneo (part 10): family Geometridae, subfamilies Sterrhinae \& Larentiinae. Malayan Nature Journal 51: 1-242.

Holloway, J.D. (1998a). The moths of Borneo (part 8): families Castniidae, Callidulidae, Drepanidae \& Uraniidae. Malayan Nature Journal 52: 1-155.

Holloway, J.D. (1998b). The moths of Borneo (part 3): superfamily Bombycoidea: families Lasiocampidae, Eupterotidae, Bombycidae,
Brahmaeidae, Saturniidae, Sphingidae. Southdene Sdn. Bhd., Kuala Lumpur, 199pp.

Holloway, J.D. (1999). The moths of Borneo (part 5): family Lymantriidae. Malayan Nature Journal 53: 1-188.

Holloway, J.D. (2001). The Moths of Borneo (Part 7): Family Arctiidae, Subfamily Lithosiinae. Southdene Sdn. Bhd., Kuala Lumpur, 486pp.

Holloway, J.D. (2003). The Moths of Borneo (Part 18): Family Nolidae. Southdene Sdn. Bhd., Kuala Lumpur. 279pp.

Holloway, J.D. (2005). The moths of Borneo: family Noctuidae, subfamily Catocalinae. Malayan Nature Journal 58(1-4): 1-529.

Holloway, J.D. (2008). The moths of Borneo: family Noctuidae, subfamilies Rivulinae, Phytometrinae, Herminiinae, Hypeninae and Hypenodinae. Malayan Nature Journal 60(1-4): 1-268.

Holloway, J.D. (2009). The moths of Borneo (part 13): family Noctuidae, subfamily Pantheinae (part), Bagisarinae, Acontiinae, Aediinae, Eustrotiinae, Bryophilinae, Araeopteroninae, Aventiinae, Eublemminae and further miscellaneous genera. Malayan Nature Journal 62(1\&2): 1-240.

Lim-Hasegawa, D. \& V.K. Chey (2009). Diversity of Lepidoptera in Imbak Canyon Conservation Area. Sepilok Bulletin 11: 15-36.

Makihara, H. (1999). Atlas of longicorn beetles in Bukit Soeharto Education Forest, Mulawarman University, East Kalimantan, Indonesia. PUSREHUT Special Publication No. 7. Mulawarman University \& JICA, 140 pp.

Mannan, S. (2011). Multi-use forest management in Sabah - the challenges and opportunities in attaining statewide certification under the Forest Stewardship Council (FSC) system. Speech delivered at the $6^{\text {th }}$ FSC General Assembly at Kota Kinabalu, Sabah on 29 June, 2011.

Meijer, W. (1996). Notes on the tree flora of Kinabalu, pp. 167-179. In: Wong, K.M. \& A. Phillips (eds.). Kinabalu: summit of Borneo. The Sabah Society \& Sabah Parks.

Mizunuma, T. \& S. Nagai (1994). The Lucanid Beetles of The World. Mushi-sha, Tokyo, Japan, 340pp.

Nilus, R., J.B. Sugau, J.T. Pereira \& S. Sabran (2012). Botanical and forest assessments of the Bukit Hampuan Forest Reserve. Departmental Report, Sabah Forestry Department.

Orr, A.G. (2003). A Guide to The Dragonflies of Borneo: Their Identification and Biology. Natural History Publications (Borneo), Kota Kinabalu, 195pp.

Otsuka, K. (1988). Butterflies of Borneo - Vol. I. Tobishima Corporation, Tokyo, Japan, 61pp.

Otsuka, K. (2001). A Field Guide to the Butterflies of Borneo and South East Asia. Hornbill Books, 224pp.

Robinson, G.S., K.R. Tuck \& M. Shaffer (1994). A Field Guide to Smaller Moths of South-east Asia. The Natural History Museum, London \& Malaysian Nature Society, 309pp.

SDR (2006). Species Diversity \& Richness Version IV. Pisces Conservation Ltd., Lymington, UK.

SFD (2010a). Fact sheets of forest reserves in Sabah. Sabah Forestry Department, 24pp.

SFD (2010b). Compilation of papers. Regional Forum on Enhancing Forest Connectivity \& Corridors within the Heart of Borneo in Sabah, 26-27 October, 2009. Kota Kinabalu, Sabah. Sabah Forestry Department, 176pp.

Tung, V. W-Y. (1983). Common Malaysian Beetles. Longman, Kuala Lumpur, 142pp.

Wong, K.M. \& A. Phillips (eds.) (1996). Kinabalu: Summit of Borneo. The Sabah Society \& Sabah Parks, 544pp.

Yong, H.S. (eds.) (2009). Proceedings of the Conference on Biodiversity and National Development: Achievements, Opportunities and Challenges. Academy of Sciences Malaysia, 216pp. 
Appendix 1. Butterflies from Bukit Hampuan Forest Reserve, Sabah (10-14 May 2010).

\begin{tabular}{|c|c|c|c|c|}
\hline & Species & Author & Family & Digital photo no. \\
\hline 1 & Appias indra plana & Butler & Pieridae & BHP1439 \\
\hline 2 & Catopsilia pomona pomona & Fabricius & Pieridae & BHP1486 \\
\hline 3 & Eurema sari sodalis & Moore & Pieridae & BHP1491 \\
\hline 4 & Leptosia nina malayana & Fruhstorfer & Pieridae & BHP1659 \\
\hline 5 & Pareronia valeria lutescens & Butler & Pieridae & spotted \\
\hline 6 & Graphium agamemnon agamemnon & Linne & Papilionidae & spotted \\
\hline 7 & Graphium antiphates itamputi & Butler & Papilionidae & BHP1665 \\
\hline 8 & Lamproptera curius curius & Fabricius & Papilionidae & BHP1675 \\
\hline 9 & Pachliopta aristolochiae antiphus & Fabricius & Papilionidae & BHP1544 \\
\hline 10 & Papilio helenus enganius & Doherty & Papilionidae & BHP1594 \\
\hline 11 & Papilio memnon memnon & Linne & Papilionidae & BHP1654 \\
\hline 12 & Papilio nephelus albolineatus & Forbes & Papilionidae & BHP1667 \\
\hline 13 & Troides brookiana brookiana & Wallace & Papilionidae & spotted \\
\hline 14 & Troides helena mosychlus & Fruhstorfer & Papilionidae & BHP1580 \\
\hline 15 & Troides sp. & & Papilionidae & spotted \\
\hline 16 & Anosia genutia intensa & Moore & Nymphalidae & BHP1671 \\
\hline 17 & Athyma clerica clerica & Butler & Nymphalidae & BHP1221 \\
\hline 18 & Athyma selenophara amhara & Druce & Nymphalidae & BHP1435 \\
\hline 19 & Cethosia hypsea hypsea & Doubleday & Nymphalidae & BHP1269, 1272 \\
\hline 20 & Euploea leucostictos syra & Fruhstorfer & Nymphalidae & BHP1649 \\
\hline 21 & Euploea diocletianus lowii & Butler & Nymphalidae & BHP1651 \\
\hline 22 & Euploea phaenareta butleri & Moore & Nymphalidae & BHP1278 \\
\hline 23 & Euploea tulliolus aristotelis & Moore & Nymphalidae & BHP1231 \\
\hline 24 & Euripus nyctelius borneensis & Distant & Nymphalidae & BHP1589 \\
\hline 25 & Hypolimnas bolina philippensis & Butler & Nymphalidae & BHP1612 \\
\hline 26 & Idea stolli virgo & Fruhstorfer & Nymphalidae & BHP1660 \\
\hline 27 & Ideopsis vulgaris interposita & Fruhstorfer & Nymphalidae & BHP1494 \\
\hline 28 & Lethe chandica delila & Staudinger & Nymphalidae & spotted \\
\hline 29 & Moduza procris agnata & Fruhstorfer & Nymphalidae & spotted \\
\hline 30 & Mycalesis anapita fucentia & Fruhstorfer & Nymphalidae & BHP1603 \\
\hline 31 & Mycalesis marginata pitan & Staudinger & Nymphalidae & BHP1195 \\
\hline 32 & Neptis leucoporos cresina & Fruhstorfer & Nymphalidae & BHP1591 \\
\hline 33 & Orsotriaena medus medus & Fabricius & Nymphalidae & BHP1682 \\
\hline 34 & Parantica aspasia aspasia & Fabricius & Nymphalidae & BHP1244 \\
\hline 35 & Parantica luzonensis praemacaristus & Fruhstorfer & Nymphalidae & BHP1264 \\
\hline 36 & Parthenos sylvia borneensis & Staudinger & Nymphalidae & spotted \\
\hline 37 & Sumalia daraxa viridans & Fruhstorfer & Nymphalidae & BHP1210 \\
\hline 38 & Symbrenthia lilaea marius & Fruhstorfer & Nymphalidae & BHP1553 \\
\hline 39 & Tirumala septentrionis microsticta & Butler & Nymphalidae & BHP1639 \\
\hline 40 & Ypthima pandocus sertorius & Fruhstorfer & Nymphalidae & BHP1192, 1215 \\
\hline 41 & Lycaenidae sp. 1 & & Lycaenidae & BHP1211 \\
\hline 42 & Koruthaialos sindu sindu & C. \& R. Felder & Hesperiidae & spotted \\
\hline
\end{tabular}


Appendix 2. Moths of Bukit Hampuan Forest Reserve, Sabah (10-14 May 2010).

\begin{tabular}{|c|c|c|c|c|c|}
\hline & Species & Author & Family & Subfamily & Digital photo no. \\
\hline 1 & Aethalida borneana & Holloway & Arctiidae & Arctiinae & BHP1363, 1710 \\
\hline 2 & Amerila astreus & Drury & Arctiidae & Arctiinae & BHP1344, 1348 \\
\hline 3 & Nyctemera kinibalina & Snellen & Arctiidae & Arctiinae & BHP1233 \\
\hline 4 & Nyctemera muelleri & Vollenhoven & Arctiidae & Arctiinae & BHP1312 \\
\hline 5 & Nyctemera tripunctaria & Linnaeus & Arctiidae & Arctiinae & BHP1219 \\
\hline 6 & Spilosoma groganae & Holloway & Arctiidae & Arctiinae & BHP1512 \\
\hline 7 & Adites hosei & Holloway & Arctiidae & Lithosiinae & BHP1366 \\
\hline 8 & Adites sp. & & Arctiidae & Lithosiinae & BHP1727 \\
\hline 9 & Barsine euprepia & Hampson & Arctiidae & Lithosiinae & BHP1347 \\
\hline 10 & Barsine roseororatus & Butler & Arctiidae & Lithosiinae & BHP1333 \\
\hline 11 & Cyana cruentata & Talbot & Arctiidae & Lithosiinae & BHP1313, 1724 \\
\hline 12 & Cyana horsfieldii & Roepke & Arctiidae & Lithosiinae & BHP1770 \\
\hline 13 & Cyana malayensis & Hampson & Arctiidae & Lithosiinae & BHP1741 \\
\hline 14 & Cyana saulia & Swinhoe & Arctiidae & Lithosiinae & BHP1729 \\
\hline 15 & Cyana sp. & & Arctiidae & Lithosiinae & BHP1751 \\
\hline 16 & Eugoa trifascia & Walker & Arctiidae & Lithosiinae & BHP1749 \\
\hline 17 & Lyclene circumdata & Walker & Arctiidae & Lithosiinae & BHP1695 \\
\hline 18 & Lyclene mesilaulinea & Holloway & Arctiidae & Lithosiinae & BHP1736 \\
\hline 19 & Lyclene multiramorum & Holloway & Arctiidae & Lithosiinae & BHP1760 \\
\hline 20 & Lyclene sp. & & Arctiidae & Lithosiinae & BHP1707 \\
\hline 21 & Monosyntaxis sp. & & Arctiidae & Lithosiinae & BHP1747 \\
\hline 22 & Padenia obliquifascia & Rothschild & Arctiidae & Lithosiinae & BHP1761 \\
\hline 23 & Teulisna sp. & & Arctiidae & Lithosiinae & BHP1730 \\
\hline 24 & Auriculoceryx pterodactyliformis & Holloway & Arctiidae & Syntominae & BHP1768 \\
\hline 25 & Mustilia dierli & Holloway & Bombycidae & & BHP1735 \\
\hline 26 & Zeuzera borneana & Roepke & Cossidae & & BHP1532 \\
\hline 27 & Zeuzera indica & Herrich-Schaffer & Cossidae & & BHP1737 \\
\hline 28 & Canucha specularis & Moore & Drepanidae & & BHP1523 \\
\hline 29 & Tridrepana flava & Moore & Drepanidae & & BHP1365 \\
\hline 30 & Amblychia infoveata & Prout & Geometridae & Ennominae & BHP1310 \\
\hline 31 & Bracca georgiata & Guenee & Geometridae & Ennominae & BHP1731 \\
\hline 32 & Dilophodes elegans & Butler & Geometridae & Ennominae & BHP1342 \\
\hline 33 & Krananda semihyalina & Moore & Geometridae & Ennominae & BHP1531 \\
\hline 34 & Milionia basalis & Walker & Geometridae & Ennominae & BHP1535 \\
\hline 35 & Ourapteryx claretta & Holloway & Geometridae & Ennominae & BHP1352 \\
\hline 36 & Plutodes argentilauta & Prout & Geometridae & Ennominae & BHP1370 \\
\hline 37 & Pogonopygia nigralbata & Warren & Geometridae & Ennominae & BHP1518 \\
\hline 38 & Agathia laetata & Fabricius & Geometridae & Geometrinae & BHP1517 \\
\hline 39 & Spaniocentra megaspilaria & Guenee & Geometridae & Geometrinae & BHP1740 \\
\hline 40 & Tanaorhinus rafflesii & Moore & Geometridae & Geometrinae & BHP1530 \\
\hline 41 & Calliteara cox & Schintlmeister & Lymantriidae & & BHP1756 \\
\hline 42 & Calliteara diplozona & Collenette & Lymantriidae & & BHP1757 \\
\hline 43 & Asota albiformis & Swinhoe & Noctuidae & Aganainae & BHP1773 \\
\hline 44 & Asota kinabaluensis & Rothschild & Noctuidae & Aganainae & BHP1511, 1521 \\
\hline 45 & Asota producta & Butler & Noctuidae & Aganainae & BHP1510 \\
\hline 46 & Clethrorasa pilcheri & Hampson & Noctuidae & Amphipyrinae & BHP1284 \\
\hline 47 & Avatha bubo & Geyer & Noctuidae & Catocalinae & BHP1297 \\
\hline 48 & Buzara saikehi & Holloway & Noctuidae & Catocalinae & BHP1283 \\
\hline 49 & Hamodes propitia & Guerin-Meneville & Noctuidae & Catocalinae & BHP1529 \\
\hline 50 & Hypopyra sp. & & Noctuidae & Catocalinae & BHP1748 \\
\hline 51 & Thyas javanica & Gaede & Noctuidae & Catocalinae & BHP1744 \\
\hline 52 & Tiracola aureata & Holloway & Noctuidae & Hadeninae & BHP1507 \\
\hline 53 & Blenina sp. & & Nolidae & & BHP1305 \\
\hline 54 & Dichocrocis zebralis & Moore & Pyralidae & Crambinae & BHP1766 \\
\hline 55 & Pachynoa purpuralis & Walker & Pyralidae & Crambinae & BHP1304 \\
\hline 56 & Botyodes asialis & Guenee & Pyralidae & Pyraustinae & BHP1361 \\
\hline
\end{tabular}




\begin{tabular}{|l|l|l|l|l|l|}
\hline & Species & Author & Family & Subfamily & Digital photo no. \\
\hline 57 & Nevrina procopia & Cramer & Pyralidae & Pyraustinae & BHP1514 \\
\hline 58 & Parotis laceritalis & Kenrick & Pyralidae & Pyraustinae & BHP1373 \\
\hline 59 & Syllepte fabiusalis & Walker & Pyralidae & Pyraustinae & BHP1513 \\
\hline 60 & Acherontia lachesis & Fabricius & Sphingidae & & BHP1339 \\
\hline 61 & Acosmeryx shervilli & Boisduval & Sphingidae & & BHP1354 \\
\hline 62 & Eurypteryx bhaga & Moore & Sphingidae & & BHP1704 \\
\hline 63 & Banisia intonsa & Whalley & Thyrididae & & BHP1728 \\
\hline 64 & Telchines vialis & Moore & Thyrididae & & BHP1754 \\
\hline 65 & Lyssa menoetius & Hopffer & Uraniidae & & BHP1746 \\
\hline 66 & Lyssa zampa & Butler & Uraniidae & & BHP1318 \\
\hline
\end{tabular}

Appendix 3. Bornean endemic moth species recorded from Bukit Hampuan Forest Reserve.

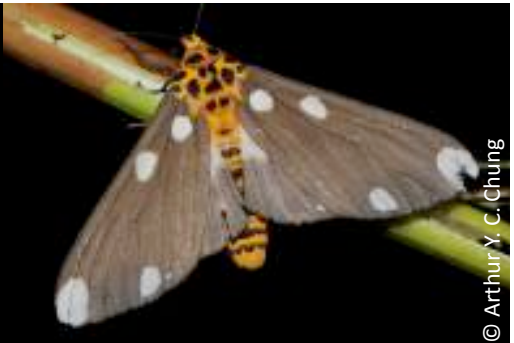

Aethalida borneana Arctiidae (Arctiinae)

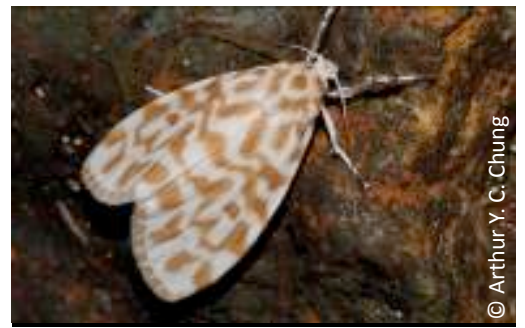

Adites hosei Arctiidae (Lithosiinae)

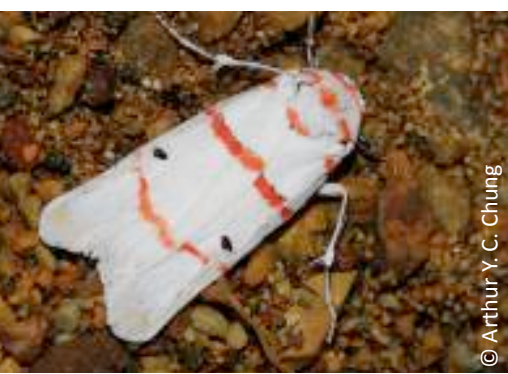

Cyana saulia Arctiidae (Lithosiinae)

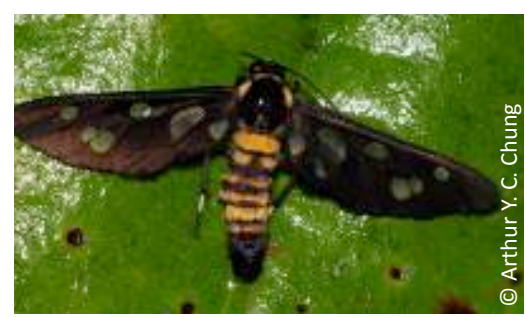

Auriculoceryx pterodactyliformis Arctiidae (Syntominae)

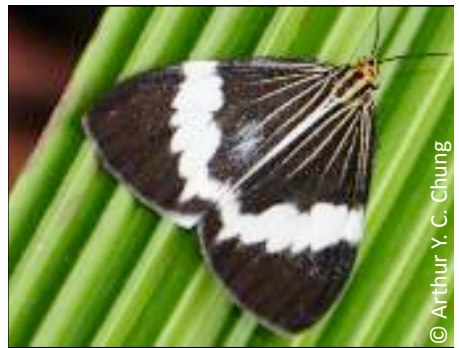

Nyctemera kinibalina Arctiidae (Arctiinae)

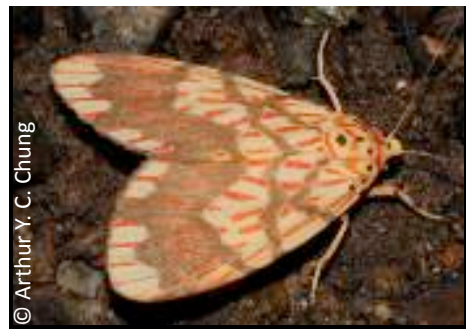

Barsine euprepia Arctiidae (Lithosiinae)

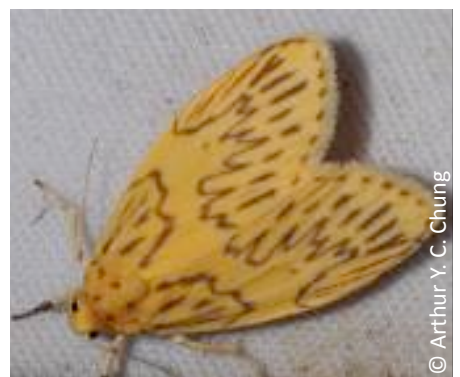

Lyclene mesilaulinea Arctiidae (Lithosiinae)

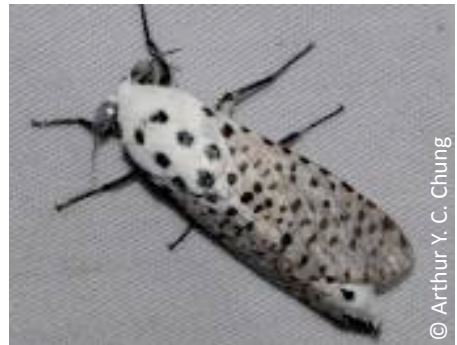

Zeuzera borneana Cossidae

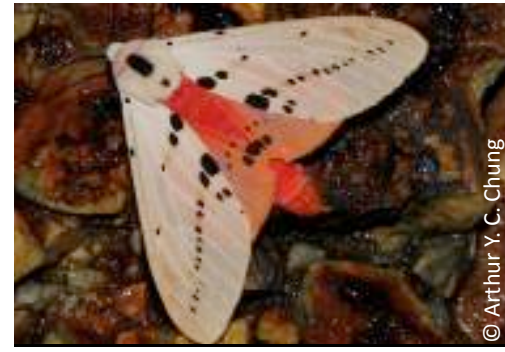

Spilosoma groganae Arctiidae (Arctiinae)

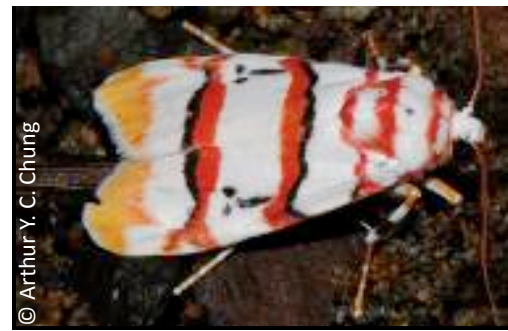

Cyana cruentata Arctiidae (Lithosiinae)

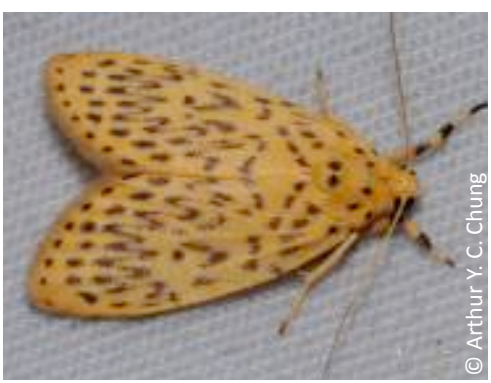

Lyclene multiramorum Arctiidae (Lithosiinae)

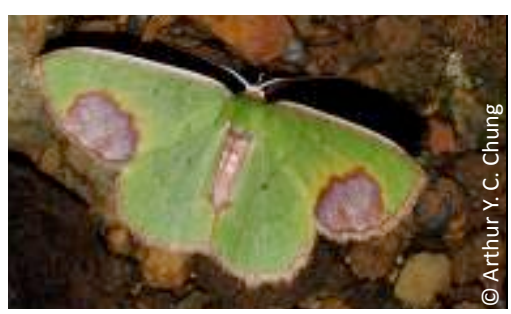

Spaniocentra megaspilaria Geometridae (Geometrinae) 


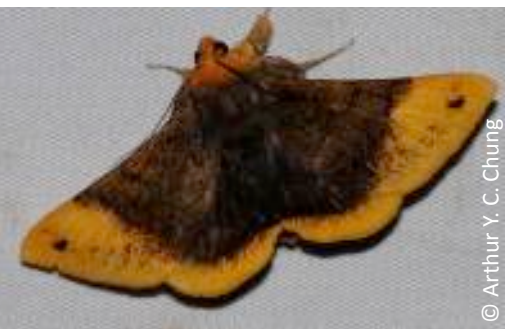

Buzara saikehi Noctuidae (Catocalinae)

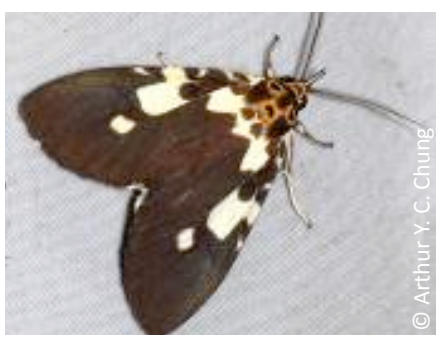

Asota kinabaluensis Noctuidae (Aganainae)

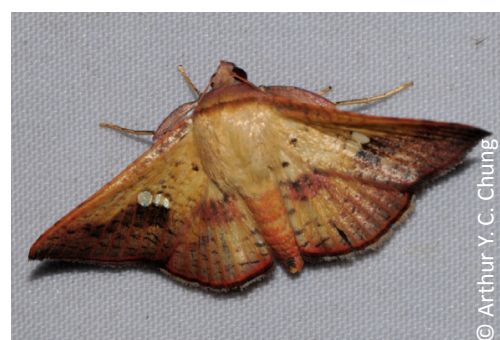

Banisia intonsa Thyrididae
Appendix 4. Beetles from Bukit Hampuan Forest Reserve, Sabah (10-14 May 2010).

\begin{tabular}{|c|c|c|c|c|}
\hline & Species & Author & Family & $\begin{array}{l}\text { Digital photo } \\
\text { no. }\end{array}$ \\
\hline 1 & Glenea elegans & Oliver & Cerambycidae & BHP1840 \\
\hline 2 & $\begin{array}{l}\text { Macrotoma } \\
\text { (Bandar) pascoei }\end{array}$ & Lansberge & Cerambycidae & BHP1383 \\
\hline 3 & $\begin{array}{l}\text { Macrotoma } \\
\text { (Bandar) ?fisheri }\end{array}$ & Waterhouse & Cerambycidae & BHP1394 \\
\hline 4 & $\begin{array}{l}\text { Megopis } \\
\text { marginalis }\end{array}$ & (Fabricius) & Cerambycidae & BHP1829 \\
\hline 5 & $\begin{array}{l}\text { Neosarmydus } \\
\text { costipennis }\end{array}$ & Fisher & Cerambycidae & BHP1567 \\
\hline 6 & Rhytidodera sp. & & Cerambycidae & BHP1831 \\
\hline 7 & Epilachna sp. & & Coccinellidae & BHP1598 \\
\hline 8 & Monochilus sp. & & Coccinellidae & BHP1240 \\
\hline 9 & Curculionidae sp. 1 & & Curculionidae & BHP1447 \\
\hline 10 & Curculionidae sp. 2 & & Curculionidae & $\begin{array}{l}\text { BHP1835, } \\
1833\end{array}$ \\
\hline 11 & Elateridae sp. 1 & & Elateridae & BHP1421 \\
\hline 12 & Elateridae sp. 2 & & Elateridae & BHP1427 \\
\hline 13 & Elateridae sp. 3 & & Elateridae & BHP1430 \\
\hline 14 & ?Eulichas sp. & & Eulichadidae & BHP1415 \\
\hline 15 & $\begin{array}{l}\text { Cyclommatus } \\
\text { giraffa }\end{array}$ & Mollenkamp & Lucanidae & $\begin{array}{l}\text { BHP1720, } \\
1717\end{array}$ \\
\hline 16 & Dorcus thoracicus & Mollenkamp & Lucanidae & BHP1425 \\
\hline 17 & $\begin{array}{l}\text { Odontolabis } \\
\text { castelnaudi }\end{array}$ & Parryi & Lucanidae & BHP1408 \\
\hline 18 & Aceraius sp. & & Passalidae & BHP1431 \\
\hline 19 & $\begin{array}{l}\text { Chalcosoma } \\
\text { moellenkampi }\end{array}$ & Kolbe & $\begin{array}{l}\text { Scarabaeidae } \\
\text { (Dynastinae) }\end{array}$ & $\begin{array}{l}\text { BHP1236, } \\
2020\end{array}$ \\
\hline 20 & Scarabaeidae sp. 1 & & $\begin{array}{l}\text { Scarabaeidae } \\
\text { (Dynastinae) }\end{array}$ & BHP1825 \\
\hline 21 & Hoplia sp. & & $\begin{array}{l}\text { Scarabaeidae } \\
\text { (Melolonthinae) }\end{array}$ & BHP1698 \\
\hline 22 & Scarabaeidae sp. 2 & & $\begin{array}{l}\text { Scarabaeidae } \\
\text { (Melolonthinae) }\end{array}$ & BHP1565 \\
\hline 23 & Anomala sp. & & $\begin{array}{l}\text { Scarabaeidae } \\
\text { (Rutelinae) }\end{array}$ & BHP1819 \\
\hline 24 & $\begin{array}{l}\text { Fruhstoferia } \\
\text { nigromuliebris }\end{array}$ & Nagai & $\begin{array}{l}\text { Scarabaeidae } \\
\text { (Rutelinae) }\end{array}$ & BHP1413 \\
\hline 25 & Scarabaeidae sp. 3 & & $\begin{array}{l}\text { Scarabaeidae } \\
\text { (Rutelinae) }\end{array}$ & BHP1558 \\
\hline 26 & Setenis sp. & & Tenebrionidae & BHP1571 \\
\hline
\end{tabular}

Appendix 5. Other insects from Bukit Hampuan Forest Reserve, Sabah (10-14 May 2010).

\begin{tabular}{|c|l|l|l|l|}
\hline & Species & Author & Family & $\begin{array}{l}\text { Digital photo } \\
\text { no. }\end{array}$ \\
\hline & Dragonflies & & & \\
\hline 1 & $\begin{array}{l}\text { Macromia } \\
\text { westwoodii }\end{array}$ & Selys & Corduliidae & BHP1617 \\
\hline 2 & Pantala flavescens & (Fabricius) & Libellulidae & BHP1806 \\
\hline 3 & Neurothemis ramburii & Brauer & Libellulidae & BHP1239 \\
\hline 4 & Crocothemis sp. & & Libellulidae & BHP1268 \\
\hline 5 & Orthetrum glaucum & Brauer & Libellulidae & BHP1225 \\
\hline 6 & Libellulidae sp. 1 & & Libellulidae & BHP1798 \\
\hline 7 & Libellulidae sp. 2 & & Libellulidae & BHP1185 \\
\hline & Cicadas & & & \\
\hline 1 & Tacua speciosa & Illiger & Cicadidae & BHP1387 \\
\hline 2 & $\begin{array}{l}\text { Platylomia } \\
\text { viridimaculata }\end{array}$ & Distant & Cicadidae & BHP1576, 1574 \\
\hline 3 & Dundubia vaginata & Fabricius & Cicadidae & BHP1774 \\
\hline 4 & Dundubia rufivena & Walker & Cicadidae & \\
\hline 5 & Tomaspididae sp. 1 & & Tomaspididae & BHP1196 \\
\hline 6 & Tomaspididae sp. 2 & & Tomaspididae & BHP1263 \\
\hline & Ant & & Myrmicinae & BHP1453 \\
\hline 1 & subcarinata & & & \\
\hline
\end{tabular}

